\title{
Comparative Study of Physical Properties of Cashew Nuts from Three Main Production Areas in Côte d'Ivoire
}

\author{
Koffi Yao Stéphane ${ }^{1^{*}}$, Kouadio James Halbin ${ }^{1,2}$, Nindjin Charlemagne ${ }^{3}$ \\ ${ }^{1}$ Research Group of Crop Production Quality Management, Laboratory of Agrovalorisation, UFR Agroforesterie, \\ Jean Lorougnon Guédé University, Daloa, Côte d'Ivoire \\ ${ }^{2}$ Laboratory of (Bio) Toxicology and Industrial Hygiene, DPPSST, Abidjan, Côte d'Ivoire \\ ${ }^{3}$ Department of Biochemistry and Tropical Products Technology, UFR STA, Nangui Abrogoua University, Abidjan, Côte d'Ivoire \\ Email: ^kystephane.sy@gmail.com
}

How to cite this paper: Stéphane, K.Y., Halbin, K.J. and Charlemagne, N. (2020) Comparative Study of Physical Properties of Cashew Nuts from Three Main Production Areas in Côte d'Ivoire. Agricultural Sciences, 11, 1232-1249.

https://doi.org/10.4236/as.2020.1112081

Received: November 9, 2020

Accepted: December 27, 2020

Published: December 30, 2020

Copyright $\odot 2020$ by author(s) and Scientific Research Publishing Inc. This work is licensed under the Creative Commons Attribution International License (CC BY 4.0).

http://creativecommons.org/licenses/by/4.0/

\begin{abstract}
The aim of our study was to evaluate physical properties of cashew nuts from the three main production areas in Côte d'Ivoire namely Bondoukou, Dabakala and Mankono after 6 months of storage in identical conditions. Sample cashew nuts have been collected from farmers randomly selected in 20 localities far enough apart and also veritable purveyors of nuts. The physical traits of the raw cashew nuts and their different parts were evaluated by standard methods. As results, our data showed that despite the similar mass (in mean $6.23 \mathrm{~g}$ ) of cashew nuts independently of the origin, the mass of the kernels nuts from Bondoukou (2.17 g) were significantly higher than those from Dabakala $(1.90 \mathrm{~g})$ and Mankono $(1.81 \mathrm{~g})$ respectively in contrast to the shell mass indicating the best kernels yield at Bondoukou. Nuts water content diminished slowly from nuts at Bondoukou (3.86\%) but rapidly at Mankono (5.68\%) after 6 months of storage. For the morphometric characteristics, our results revealed that the nuts from Bondoukou were statistically shorter but the kernels were thicker $(15.1 \pm 0.50 \mathrm{~mm})$ versus and for Dabakala (11.4 \pm $0.16 \mathrm{~mm})$ and Mankono $(11.2 \pm 0.19 \mathrm{~mm})$ respectively. There is a clear correlation between the arithmetic diameter of the kernels and their sphericity $(r$ $=0.99$ ). Concerning the technological properties, out-turn was average ranged from 44.09 to 46.69 with defective up to $18 \%$ at Dabakala. Taken together, our results suggested that the cashew nuts presented different physical properties according to each region of production in Côte d'Ivoire requiring appropriated agricultural practices.
\end{abstract}




\section{Keywords}

Cashew Nuts, Physical Properties, Defects, Côte d'Ivoire

\section{Introduction}

Cashew (Anacardium occidentale L.) of family Anacardiaceae, order Sapindales, is a fruit-cum-nut crop of world importance and is an important tropical plant species native to tropical America [1]. Anacardium species have significant economic importance throughout the world, principally because of two of its natural products: the cashew nut itself (botanically, the fruit) and the pseudofruit (which is actually an expanded and fleshy peduncle). The cashew tree represents for Africa which provides $50 \%$ of the world's supply of raw cashew nuts, a great opportunity through the export of its nuts [2] [3].

Introduced in the North of Côte d'Ivoire at the end of the 1950s by Government programs of reforestation due to its rapid growth and its rusticity, cashew was until the early 1990s exploited for its wood [4] [5] [6]. But since the beginning of the 2000s, cashew plantations have emerged gradually as income-generating speculation in front of cotton [4] [5] [6]. Thus, the production of cashew has been very intensive in Côte d'Ivoire since 2015 with annual productions estimated at 700 thousand tons representing a rate of $21 \%$ of the World offer. Côte d'Ivoire is currently the world leading producer and exporter country of cashew. More than 250 thousand producers are concerned by cashew which represents the main source of income of approximately 1.5 million Ivorian people [4]. Despite the enormous potential for cashew revenue in Côte d'Ivoire, the cashew production is characterized not only by low-yields, but also by a less competitive quality of nuts internationally [7] [8]. Now, In the international market, the quality of raw cashew nuts is crucial in setting its price [9]. The quality index used to measure the quality of raw cashew nuts is the Out-turn sometimes called KOR (Kernel Output Ratio) [10]. It is expressed in lbs raw cashew nut quality, which just means the weight of useful kernels weighed in pounds in one bag of $80 \mathrm{~kg}$ of raw nuts. In addition, the moisture criterion used in controlling the commercial quality of nuts is an important factor whose control could impact nut conservation [11]. It has been reported that foods with low moisture content and high percentage of fat such as cashew nuts become vulnerable to deterioration such as oxidation and moisture absorption reactions, which leads to microbiological changes, texture and loss of crispness [12] [13].

In Côte d'Ivoire, despite measures taken to improve the quality of cashew nuts, it appears that it remains poor or classed acceptable [14] because of the moisture levels often above the $10 \%$, the standard. That could explain Ivorian cashew nuts quality degradation [15] and an Out-turn average ranged between 46 and $48 \mathrm{lbs}$ compared to 47 to $49 \mathrm{lbs}$ in Benin and Nigeria and 50 to $52 \mathrm{lbs}$ in Senegal and Guinea-Bissau respectively [3] [16]. These characteristics are mainly 
related to agronomic traits such as size (length, width, thickness, geometric and arithmetic diameters), weight and morphological properties (sphericity, elongation, flattening) of raw cashew nuts and their kernel [10] [14] [17] [18]. However, the results of existing physico-mechanical characterisation work reveal that the variability of the dimensional properties is attributed to the agro-ecological and climatic factors of the production zones [19]. Indeed, the diversity of ecological regions combined with poor harvesting and post-harvest practices could constitute a major constraint to managing the quality of the nuts produced [3] [19] [20]. In some countries such as Nigeria, India, Benin, Senegal where the problem of nut quality is acute, the characterization of physical and sanitary properties according to geographical origin provides a clear answer in the management of nut quality in these different countries [17] [21] [22].

In Côte d'Ivoire, apart from the work of the national agricultural research centre (CNRA) on genotypic screening of high-yielding cashew nuts [14], and on cashew nut pests [23], the cashew nut sector has benefited from few research and development projects in nut quality management. The characterization of the physical and sanitary properties of raw cashew nuts, which would allow the definition of the map of nut quality according to the producing regions in Côte d'Ivoire, has not yet been the subject of scientific study. In short, there is a lack of factors necessary at the management of quality in the production process, but also to take into account for the design of equipment and various treatment processes (harvesting, transport, drying, etc.) [24].

With this problem, the promotion and management of the quality of Ivorian cashew nuts require an in-depth study on the morphometric characteristics and the extent of defects in the nuts of $A$. occidentale $\mathrm{L}$. according to the producing regions in Côte d'Ivoire [18] [25]. Hence the interest of carrying out this study to contribute to the improvement of cashew nut quality in Côte d'Ivoire.

\section{Material and Methods}

\subsection{Site of Study}

The study was conducted in the three main production areas of Côte d'Ivoire namely Bondoukou, Dabakala and Mankono. These three regions have been partitioned in 20 localities which are far enough apart and also high purveyors of nuts from the area (Figure 1).

\subsection{Collection of Cashew Nuts Samples}

The study focused on dried cashew nuts collected during the period from February to May, 2018 and stored in jute bags at ambient temperature during 6 months at Bouake town, a main site of storage of national production.

A sample between 1 to $3 \mathrm{~kg}$ of cashew nuts has been collected at the end of the drying process from farmers in the selected localities. A total of $342 \mathrm{~kg}, 263 \mathrm{~kg}$ and $247 \mathrm{~kg}$ of raw nuts were collected in the Mankono, Dabakala and Bondoukou zones respectively. After each collect, the nuts were immediately transported 


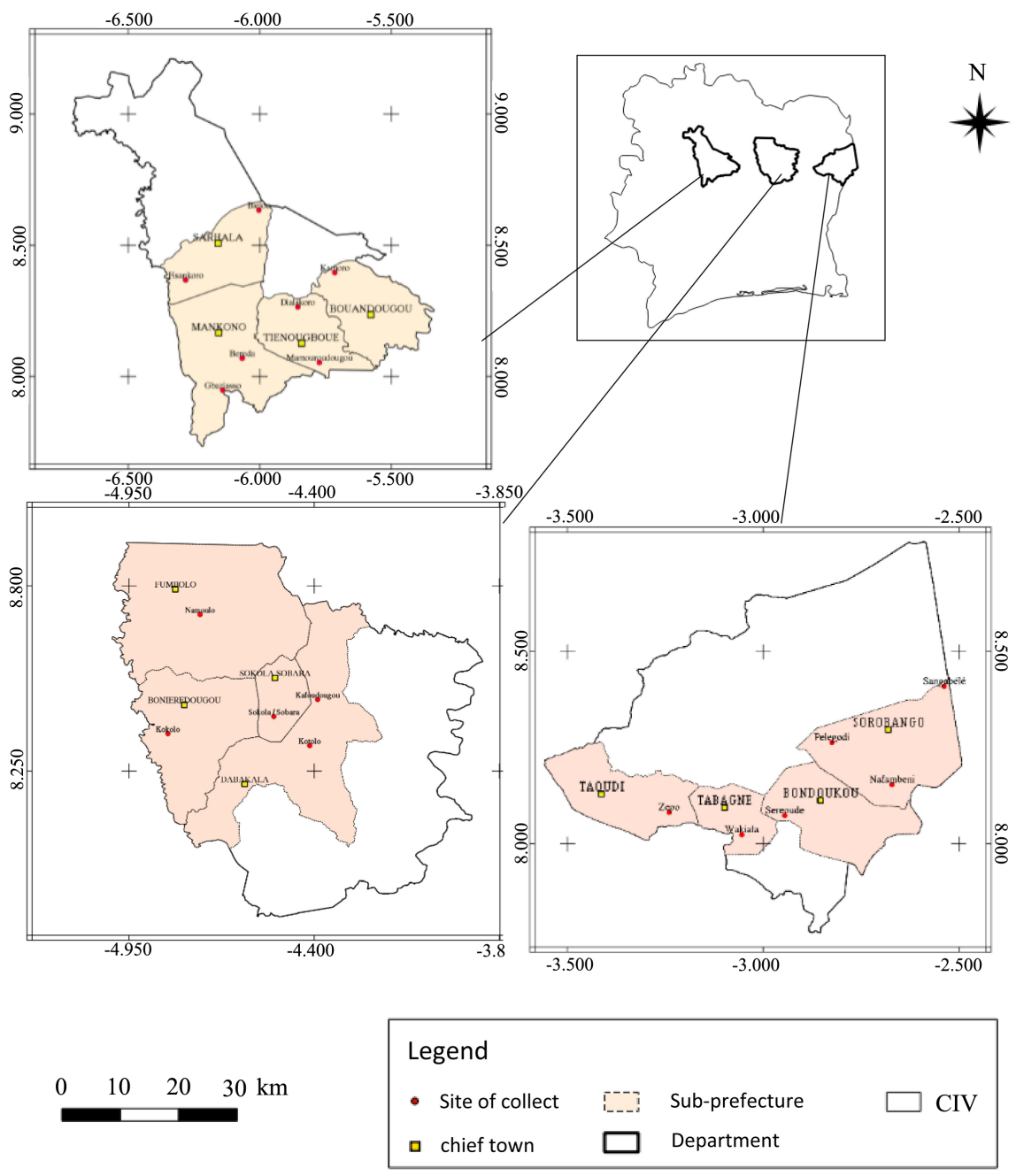

Figure 1. Location map of study sites.

to laboratory where bulk samples of different zones were selected randomly and moisture content of the nut were measured. In addition, at the sixth month of stockage, $30 \mathrm{~kg}$ incremental sample was taken from each mother sample and transferred to the laboratory where $10 \mathrm{~kg}$ sub-samples were achieved according to the quarter method [14].

\subsection{Determination of Cashew Nuts Physical Properties}

\subsubsection{Moisture Content}

Moisture content has been measured in kernels according to the [26] method just after drying process $\left(\mathrm{P}_{0}\right)$ and after 6 month of storage $\left(\mathrm{P}_{6}\right)$. One hundred (100) kernels of each zone were cut into small pieces of approximately $3 \mathrm{~mm}$ thickness and homogenized. Then $3 \mathrm{~g}(M 0)$ have been dried during 24 hours in a hot-air oven (Memmert, model SCHWABACH 854, Germany) at $105^{\circ} \mathrm{C}$ and weighed after leaving in a desiccator for $30 \mathrm{~min}$. The Moisture content was calculated according to the Formula (1) and the water loss in kilograms per kilogram of nuts on a wet basis according to Formula (2): 


$$
M_{k}=\frac{m_{i}-m_{f}}{m_{i}} \times 100
$$

and

$$
X=\frac{M_{k}}{100}
$$

where: $m$ is mass in $g, X$ is water lost and the subscripts $i$, and $f$ stand for initial and final, respectively.

\subsubsection{Mass Determination and Proportion}

To determine the mass of a single cashew nut and kernel, 100 nuts and kernels from the bulk sample were selected. Mass of the selected sample was measured by a digital balance with an accuracy of $0.01 \mathrm{~g}$. To determine 1000 cashew nuts and kernels mass, 100 nuts and kernels were selected; the weight of 100 nuts and kernels were measured. Then the weight of 100 nuts and kernels was multiplied by 10 to determine 1000 nuts and kernels mass. Measuring the 1000 cashew nuts and kernels were done with 5 repetitions for each production area. Then, different parts of nut namely the shell, kernel and pellicle were carefully separated and weighed individually in order to assess their mass proportions (\%) in total mass of cashew nut. The proportion in \% of shell $P_{s}$, of kernel $P_{k}$ or of pellicle $P_{n}$, was calculated from the following formula used by [27].

$$
P_{s}=\frac{m_{s}}{m_{n}} \times 100 \text { or } P_{k}=\frac{m_{k}}{m_{n}} \times 100 \text { or } P_{s}=\frac{m_{p}}{m_{n}} \times 100
$$

where: $m_{n}, m_{s}, m_{k}, m_{p}$ are the mass in $g$ of whole nut, of shell, of kernel and of pellicle respectively.

\subsubsection{Dimensional Properties}

Morphometric characteristics have been measured on a sample of 300 nuts taken at random from the sub-sample of each production area (Bondoukou, Dabakala and Mankono). For each individual cashew nut, three main dimensions, namely length $(L)$, width $(W)$, and thickness $(T)$ were measured. For measuring principal dimensions of the kernel, cashew nut was manually broken; then length $(I)$, width $(w)$ and thickness $(t)$ of the kernel were measured. For all measurements, a digital caliper with accuracy of $0.01 \mathrm{~mm}$ was used. The Elongation $(E)$, Degree of flattening $(F)$, arithmetic mean diameter $(A M D)$, geometric mean diameter $(G M D)$, and sphericity $(\varphi)$ of the nuts and kernels were determined using the following Equations (4), (5), (6) given by [28] and Equations (7) and (8) given by and [29]:

$$
\begin{gathered}
E=\frac{L}{W} \\
F=\frac{W}{T} \\
A M D=\frac{L+W+T}{3}
\end{gathered}
$$




$$
\begin{aligned}
& G M D=\sqrt[3]{L W T} \\
& \varphi=\frac{\sqrt[3]{L W T}}{L} \times 100
\end{aligned}
$$

The volume $(V)$, the projected area and the surface area $(S)$ of cashew nuts and kernels can be calculated by obtaining the value sphere of its geometric mean diameter. These parameters were calculated using Equations (9), (10) and (11), cited by [29]:

$$
\begin{gathered}
S=\pi \times D g^{2} \\
V=\frac{\pi \times D g^{3}}{6} \\
A p=\frac{\pi \times W L}{4}
\end{gathered}
$$

\subsection{Determination of Cashew Nuts Technological Properties}

The quality criteria taken in our study were kernel graining, kernel weight and out-turn and they were calculated according to the following method described.

\subsubsection{Nut Count or Graining}

The nut count or graining in nuts $\mathrm{kg}^{-1}$ is the number of individual nuts in the one (1) kilogram raw cashew nut samples.

\subsubsection{Cutting Test}

One (1) kilogram each of the raw cashew nuts were cut through the line of intersection shell, the shells were separated from the kernel. The kernels were then separated into three different grades namely kernels accepted at 100\%, kernels accepted at 50\% (Spotted and immature kernels) and rejected kernels (moldy, butter and rotten kernels, void and diseased nuts) using standard quality chart under good lighten. All the grades were weighed separately.

\subsubsection{Total Useful Kernels}

The usable kernel $\left(U_{k}\right)$ or Total Useful Kernels of cashews nut reflects the amount of healthy kernels in a one kilogram sample of nuts. The usable kernel in $\mathrm{g}$ has been calculated using the following formula given by [25]:

$$
U_{k}=m_{100}+\frac{m_{50}}{2}
$$

where $m_{100}$ is total weight of the kernels + pellicles of nuts accepted at $100 \%$ and $m_{50}$ is total weight obtained from the kernels + pellicles of nuts accepted at $50 \%$.

\subsubsection{Out-Turn}

The out-turn $(O T)$ is expressed in Lbs units. It was calculated using the following Equation (12) as reported by [9].

$$
O T=U_{k} \times \frac{80}{454}
$$




\subsection{Statistical Analysis of Data}

All data were collected in four replicates. The collected data were analysed using Statistica 7.1 software. The comparison of averages to detect significant differences in size, shape and defects of the nuts according to the production area was carried out by the Student Newmann-keuls test with the analysis of variance (ANOVA). The relationships linking the physical properties of cashew nuts have been evaluated by calculating correlation coefficients whose significance level has been set at the probability threshold of 0.05 .

\section{Results}

\subsection{Cashew Nuts Physical Aspects}

\subsubsection{Water Content}

Moisture or water content values were summarized in Table 1. The values of moisture content just after drying process $\left(\mathrm{P}_{0}\right)$ were ranged from $12.48 \% \pm$ $0.73 \%$ (nuts from Dabakala) to $12.81 \% \pm 0.74 \%$ (nuts from Bondoukou) and seemed similar independently to the production area. Surprisingly, despite the same conditions of storage $\left(31^{\circ} \mathrm{C} \pm 2^{\circ} \mathrm{C}\right.$ and $77 \% \pm 9 \%$ relative humidity), after 6 months of storage $\left(\mathrm{P}_{6}\right)$, nuts from Mankono were much drier with water content $(7.03 \% \pm 0.37 \%)$ as compared to those from Bondoukou $(8.95 \% \pm 0.25 \%)$. Logically, the rate of water loss from nuts was proportionally to water content. Thus, the rate of water loss was lower at Bondoukou as compared to those from Dabakala and Mankono respectively (Figure 2).

\subsubsection{Mass and Mass Proportions}

Regarding the weight analysis of raw cashew nuts and its different parts, despite the similar mass of nuts independently of the origin (in mean $6.226 \mathrm{~g}$ ), the kernels of nuts from Bondoukou weighed higher with mass average $2.16 \pm 0.45 \mathrm{~g}$ corresponding to $34.90 \% \pm 4.96 \%$ of nuts total mass as compared to Dabakala $(1.90 \pm 0.33 \mathrm{~g} ; 30.81 \% \pm 3.53 \%)$ and Mankono $(1.81 \pm 0.38 \mathrm{~g} ; 29.27 \pm 3.63)$

Table 1. Moisture content of cashew nuts from different production areas during the study.

\begin{tabular}{ccccc}
\hline \multirow{2}{*}{ Production areas } & Period & \multicolumn{3}{c}{ Moisture content (\%) } \\
\cline { 3 - 5 } & & Max & Min & Mean \\
\hline \multirow{2}{*}{ Bondoukou } & $\mathrm{P}_{0}$ & 13.80 & 11.97 & $12.81 \pm 0.74$ (a) \\
& $\mathrm{P}_{6}$ & 9.62 & 8.74 & $8.95 \pm 0.23$ (b) \\
& $\mathrm{P}_{0}$ & 13.47 & 11.43 & $12.48 \pm 0.73$ (a) \\
Dabakala & $\mathrm{P}_{6}$ & 8.74 & 6.86 & $7.83 \pm 0.57$ (c) \\
& $\mathrm{P}_{0}$ & 14.13 & 11.37 & $12.79 \pm 1.15$ (a) \\
Mankono & $\mathrm{P}_{6}$ & 7.77 & 6.73 & $7.03 \pm 0.35$ (d) \\
& &
\end{tabular}

$\mathrm{P}_{0}$ is the period just after drying process, $\mathrm{P}_{6}$ is period of 6 months of nuts storage. Data are mean values \pm standard deviation. ${ }^{a, b, c, d}$ Means of the same Period $\left(\mathrm{P}_{0}\right.$ or $\left.\mathrm{P}_{6}\right)$ with different letters are significantly different $(\mathrm{p}<0.05)$. 


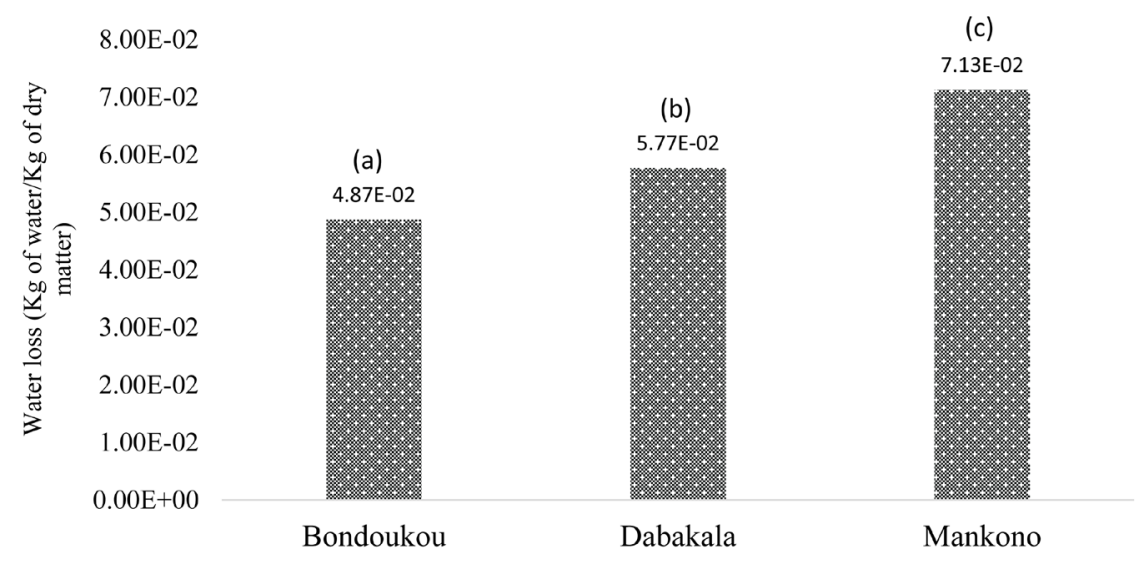

Figure 2. Cashew nut water loss according to production area after 6 months of storage.

respectively. Logically, the cashew shell mass proportion from Dabakala $(64.50 \%$ $\pm 3.46 \%)$ and Mankono $(66.80 \% \pm 4.08 \%)$ were higher and significantly different depending on the origin of the nuts. In addition, the calculation of the kernel/shell weight ratio indicated that 0.58 for nuts from Bondoukou, 0.48 from Dabakala and 0.44 from Mankono (Table 2). Moreover, the pellicle mass proportion seemed higher at Mankono but similar for both Dabakala and Bondoukou (Table 2).

\subsection{Dimensional Aspects}

Length, width, and thickness of cashew nuts and kernels and are shown in Table 3. The size of the nuts (width, thickness) and kernels (length, width) from Bondoukou, Dabakala and Mankono areas seemed similar. The width of the nut samples from different areas ranged from $22.8 \pm 2.8$ to $23.5 \pm 2.3 \mathrm{~mm}$, while the thickness was between $16.4 \pm 1.6$ to $16.7 \pm 1.9 \mathrm{~mm}$. The length of their kernels ranged from $22.8 \pm 3.1$ to $23.6 \pm 3.8 \mathrm{~mm}$ and the width between $9.9 \pm 1.4$ and $10.5 \pm 3.2 \mathrm{~mm}$. Interestingly, the results showed that the nuts produced at Bondoukou were statistically shorter $(28.5 \pm 2.8 \mathrm{~mm})$ but with thicker kernels in the order of $15.1 \pm 5.0 \mathrm{~mm}$.

The dimensional properties of nut and kernels of cashew were summarized in Table 3. The elongation, flattening and geometric mean diameter (GMD) of nuts seemed to be similar independently to the origin (Bondoukou, Mankono and Dabakala). They ranged from $1.25 \pm 0.11$ to $1.28 \pm 0.11,1.41 \pm 0.15$ to $1.43 \pm$ 0.14 and $22.0 \pm 2.0$ to $22.6 \pm 2.0 \mathrm{~mm}$ respectively. On the other hand, the arithmetic mean diameters (AMD) and nut sphericity $(\varphi)$ of nuts were significantly modulated by their origin. Indeed, at Bondoukou, our results revealed AMD $(22.46 \pm 1.65 \mathrm{~mm}) ; \varphi(77.20 \pm 4.13 \%)$ significantly different as compared to those from Dabakala (AMD = 23.16 $\pm 1.38 \mathrm{~mm} ; \varphi=75.74 \pm 2.94 \%$ ) and Mankono (AMD $=23.22 \pm 1.89 \mathrm{~mm} ; \varphi=75.33 \pm 10.74 \%$ ). For cashew kernels, the results showed a remarkable disparity in the dimensional properties according to their provenance. The values of elongation, fattening, arithmetic and geometric 
Table 2. Variation in the mass and proportions of the cashew nut, kernel, shell and pellicle by production area.

\begin{tabular}{|c|c|c|c|c|c|c|c|c|c|c|}
\hline \multirow{2}{*}{ Parameters } & \multirow{2}{*}{ Part of nut } & \multicolumn{3}{|c|}{ Bondoukou } & \multicolumn{3}{|c|}{ Dabakala } & \multicolumn{3}{|c|}{ Mankono } \\
\hline & & Max & Min & Mean & Max & Min & Mean & Max & Min & Mean \\
\hline \multirow{3}{*}{ Mass/g } & whole nut & 9.22 & 3.65 & $6.19 \pm 1.45(\mathrm{a})$ & 8.54 & 4.37 & $6.21 \pm 1.31(\mathrm{a})$ & 9.74 & 3.44 & $6.24 \pm 1.46(\mathrm{a})$ \\
\hline & kernel & 3.23 & 0.94 & $2.16 \pm 0.45(\mathrm{a})$ & 2.79 & 1.35 & $1.90 \pm 0.33(b)$ & 2.90 & 1.07 & $1.81 \pm 0.38(b)$ \\
\hline & shell & 5.49 & 2.16 & $3.74 \pm 0.80$ (a) & 5.52 & 2.53 & $3.99 \pm 0.71(\mathrm{a})$ & 6.64 & 2.14 & $4.08 \pm 1.01(\mathrm{a})$ \\
\hline \multirow{4}{*}{ Proportion/\% } & whole nut & - & - & - & - & - & - & - & - & - \\
\hline & kernel & 45.18 & 14.64 & $34.90 \pm 4.96(\mathrm{a})$ & 38.99 & 24.35 & $30.81 \pm 3.53(b)$ & 40.43 & 18.14 & $29.27 \pm 3.63(\mathrm{c})$ \\
\hline & Shell & 80.96 & 49.54 & $60.21 \pm 3.63$ (a) & 86.19 & 56.50 & $64.50 \pm 3.46(b)$ & 73.67 & 44.58 & $66.80 \pm 4.08(\mathrm{c})$ \\
\hline & pellicle & 28.04 & 2.64 & $5.40 \pm 3.59(\mathrm{a})$ & 19.02 & 2.27 & $5.04 \pm 2.14(\mathrm{a})$ & 26.72 & 0.20 & $5.67 \pm 3.31(\mathrm{a})$ \\
\hline
\end{tabular}

Data are mean values \pm standard deviation. ${ }^{\mathrm{a}, \mathrm{b}, \mathrm{c}}$ Means of the same line with different letters are significantly different $(\mathrm{p}<0.05)$.

Table 3. Physical properties of nuts, kernels, shell and pellicle of Anacardium occidentale L.

\begin{tabular}{|c|c|c|c|c|c|c|c|c|c|c|}
\hline \multirow{2}{*}{ Particle } & \multirow{2}{*}{$\begin{array}{c}\text { Dimensional } \\
\text { parameters }\end{array}$} & \multicolumn{3}{|c|}{ Bondoukou } & \multicolumn{3}{|c|}{ Dabakala } & \multicolumn{3}{|c|}{ Mankono } \\
\hline & & $\operatorname{Max}$ & Min & Mean & $\operatorname{Max}$ & Min & Mean & $\operatorname{Max}$ & Min & Mean \\
\hline \multirow{9}{*}{ Nut } & $\mathrm{L} / \mathrm{mm}$ & 42.60 & 21.10 & $28.50 \pm 2.8^{\mathrm{a}}$ & 44.10 & 21.50 & $29.73 \pm 2.66^{b}$ & 35.5 & 17.00 & $29.34 \pm 4.49^{b}$ \\
\hline & $\mathrm{W} / \mathrm{mm}$ & 43.60 & 11.80 & $23.21 \pm 2.79^{\mathrm{a}}$ & 29.20 & 17.80 & $23.37 \pm 2.08^{\mathrm{a}}$ & 30.50 & 16.00 & $23.33 \pm 2.34^{\mathrm{a}}$ \\
\hline & $\mathrm{T} / \mathrm{mm}$ & 25.60 & 11.50 & $16.74 \pm 1.84^{\mathrm{a}}$ & 23.00 & 12.00 & $16.48 \pm 1.61^{\mathrm{a}}$ & 26.80 & 11.00 & $16.72 \pm 1.91^{\mathrm{a}}$ \\
\hline & $\mathrm{GMD} / \mathrm{mm}$ & 33.35 & 17.47 & $22.48 \pm 2.03$ & 28.23 & 17.44 & $22.51 \pm 1.66$ & 31.11 & 14.41 & $22.48 \pm 2.00$ \\
\hline & $\varphi / \%$ & 95.08 & 60.46 & $76.59 \pm 3.85^{\mathrm{a}}$ & 99.98 & 52.49 & $75.92 \pm 4.04^{\mathrm{b}}$ & 97.95 & 35.07 & $77.09 \pm 4.74^{\mathrm{b}}$ \\
\hline & $\mathrm{E} /-$ & 2.50 & 0.69 & $1.27 \pm 0.11$ & 2.32 & 0.86 & $1.28 \pm 0.11$ & 3.79 & 0.89 & $1.26 \pm 0.17$ \\
\hline & $\mathrm{F} /-$ & 2.41 & 0.72 & $1.39 \pm 0.17$ & 1.90 & 0.99 & $1.43 \pm 0.14$ & 1.92 & 0.85 & $1.41 \pm 0.15$ \\
\hline & $\mathrm{S} / \mathrm{mm}^{2}$ & 3493.30 & 958.98 & $1600.87 \pm 298.16$ & 2503.30 & 955.19 & $1600.15 \pm 235.41$ & 3039.64 & 652.32 & $1600.09 \pm 284.28$ \\
\hline & $\mathrm{Ap} / \mathrm{mm}^{2}$ & 1137.57 & 268.04 & $540.08 \pm 108.80$ & 829.76 & 309.01 & $548.07 \pm 84.68$ & 1630.16 & 213.63 & $541.48 \pm 116.80$ \\
\hline \multirow{10}{*}{ kernel } & $\mathrm{L} / \mathrm{mm}$ & 31.50 & 14.00 & $23.64 \pm 3.15^{\mathrm{a}}$ & 26.60 & 19.40 & $23.59 \pm 1.70^{\mathrm{a}}$ & 30.00 & 12.20 & $22.84 \pm 3.08^{\mathrm{a}}$ \\
\hline & $\mathrm{W} / \mathrm{mm}$ & 15.80 & 6.50 & $10.40 \pm 2.59^{\mathrm{a}}$ & 13.40 & 6.10 & $9.90 \pm 1.37^{\mathrm{a}}$ & 24.90 & 6.30 & $10.48 \pm 2.57^{\mathrm{a}}$ \\
\hline & $\mathrm{T} / \mathrm{mm}$ & 30.60 & 9.00 & $15.15 \pm 4.73^{\mathrm{a}}$ & 16.00 & 5.60 & $11.38 \pm 1.58^{\mathrm{b}}$ & 20.80 & 5.00 & $11.20 \pm 1.91^{\mathrm{b}}$ \\
\hline & $\mathrm{AMD} / \mathrm{mm}$ & 23.47 & 12.13 & $16.40 \pm 2.69^{a}$ & 17.70 & 11.37 & $14.96 \pm 1.22^{\mathrm{b}}$ & 23.57 & 8.03 & $14.84 \pm 1.93^{\mathrm{b}}$ \\
\hline & $\mathrm{GMD} / \mathrm{mm}$ & 22.25 & 11.15 & $15.33 \pm 2.71^{\mathrm{a}}$ & 16.65 & 9.90 & $13.81 \pm 1.29^{\mathrm{b}}$ & 23.16 & 7.55 & $13.80 \pm 1.90^{\mathrm{b}}$ \\
\hline & $\varphi / \%$ & 94.97 & 51.56 & $65.09 \pm 9.21^{\mathrm{a}}$ & 65.40 & 47.60 & $58.55 \pm 3.81^{\mathrm{b}}$ & 92.72 & 46.31 & $60.84 \pm 7.09^{b}$ \\
\hline & $\mathrm{E} /-$ & 3.54 & 1.44 & $2.36 \pm 0.44^{\mathrm{a}}$ & 3.57 & 1.76 & $2.42 \pm 0.31^{\mathrm{b}}$ & 3.04 & 0.88 & $2.24 \pm 0.37^{\mathrm{b}}$ \\
\hline & $\mathrm{V} / \mathrm{mm}^{3}$ & 5768.12 & 725.94 & $2068.23 \pm 1200.79$ & 2417.77 & 508.32 & $1413.56 \pm 374.35$ & 6501.84 & 225.37 & $1456.84 \pm 765.47$ \\
\hline & $\mathrm{S} / \mathrm{mm}^{2}$ & 1555.39 & 390.62 & $760.76 \pm 282.46$ & 871.15 & 308.02 & $604.16 \pm 109.46$ & 1684.64 & 179.09 & $609.04 \pm 184.12$ \\
\hline & $\mathrm{Ap} / \mathrm{mm}^{2}$ & 390.89 & 89.34 & $197.10 \pm 69.60$ & 254.88 & 104.44 & $184.26 \pm 33.83$ & 468.88 & 60.37 & $190.02 \pm 61.14$ \\
\hline
\end{tabular}

(L) was the length, (W) the width, (T) the thickness, (AMD) the arithmetic mean diameter, (GMD) the geometric mean diameter, ( $\varphi$ ) the sphericity, (E) the elongation, (F) the degree of flattening, (V) the volume, (S) the surface area and (Ap) the projected area of nuts and kernels. Data are maximum, minimum, mean \pm standard deviation values. ${ }^{a, b, c}$ Means of the same line with different letters are significantly different $(\mathrm{p}<0.05)$. 
mean diameters, spehricity of kernels from Bondoukou were significantly different to those from Mankono and Dabakale (Table 3).

Analysis of the correlation between dimensional parameters showed that the mass of the cashew nut is significantly and positively correlated with its length ( $r$ $=0.79)$, width $(r=0.73)$ and thickness $(r=0.65)$. For the kernel, there was a correlation between its mass and that of the raw nut $(r=0.7)$. As for the shape of the nuts, we observed that their elongation was negatively and significantly correlated with the geometric mean diameter $(r=-0.78)$. The strongest correlations had been obtained between the arithmetic mean diameter of kernels and its sphericity $(r=0.99)$ and the arithmetic mean diameter of nuts $(r=0.99)$ and their sphericities (Table 4).

\subsection{Effect of Production Areas on the Aspect Dimension of Kernels and Nuts}

The F1 and F2 axes of the Principal Component Analysis (PCA) explained all $(100 \%)$ of the variances (Figure 3 and Figure 4). Observation of the correlation circles (Figure 3(a) and Figure 4(a)) showed that all the parameters studied were well represented. The PCA scatterplot of the production areas revealed three classes according to their similarity criteria (Figure 3(b) and Figure 4(b)). Class I, represented by the Bondoukou area, was characterized by much larger nuts with larger flat areas (Figure 3(a)). These nuts abounded with kernels whose majority of the physical properties studied (the length, the thickness, the arithmetic mean diameter, the geometric mean diameter, the sphericity, the volume, the surface area and the projected area of kernels) were greater than those of kernels from Dabakala and Mankono (Figure 4(a)). Class II is represented by the Mankono area. This zone produced spherical nuts (Figure 3(a)) containing large and flat kernels (Figure 4(a)). The Dabakala area was the class III. Analysis of the results in Figure 3(a) revealed several characteristics of these nuts. They were both elongated and wide, with larger arithmetic and geometric diameters. However, these nuts were flatter as compared to those from bondoukou and Mankono nuts. Elongated almonds were also found (Figure 4(a)).

Table 4. Characteristics of cashew nuts in the different growing areas.

\begin{tabular}{cccc}
\hline & Bondoukou & Dabakala & Mankono \\
\hline $\begin{array}{c}\text { graining } \\
\left(\text { nut } \cdot \mathrm{kg}^{-1}\right)\end{array}$ & $160.87 \pm 6.99^{\mathrm{a}}$ & $160.91 \pm 4.07^{\mathrm{a}}$ & $162.14 \pm 9.53^{\mathrm{a}}$ \\
$\begin{array}{c}\text { Kernel weight } \\
(\mathrm{g})\end{array}$ & $264.97 \pm 6.14^{\mathrm{a}}$ & $250.23 \pm 3.88^{\mathrm{b}}$ & $264.38 \pm 0.78^{\mathrm{a}}$ \\
$\begin{array}{c}\text { Defect rate } \\
(\%)\end{array}$ \\
$\begin{array}{c}\text { Out-turn } \\
(\mathrm{lbs} / \text { bag of } 80 \mathrm{~kg})\end{array}$
\end{tabular}

On each line, the values followed by the same letters do not differ significantly at the $5 \%$ threshold according to the Newman-Keuls average comparison test. ${ }^{\mathrm{a}, \mathrm{b}}$ Means of the same line with different letters are significantly different $(\mathrm{p}<0.05)$. 


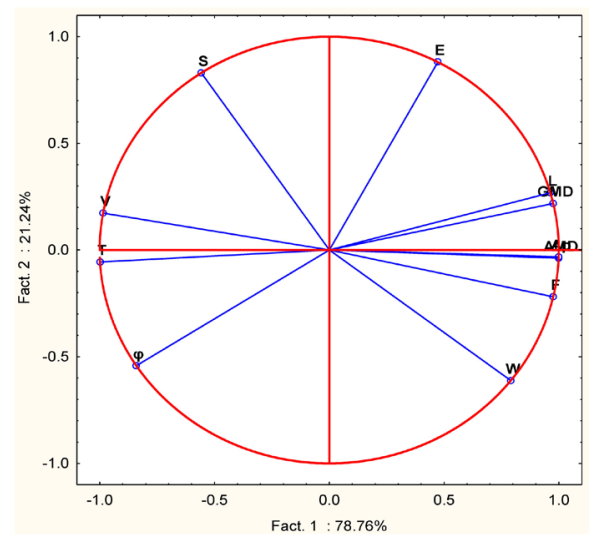

(a)

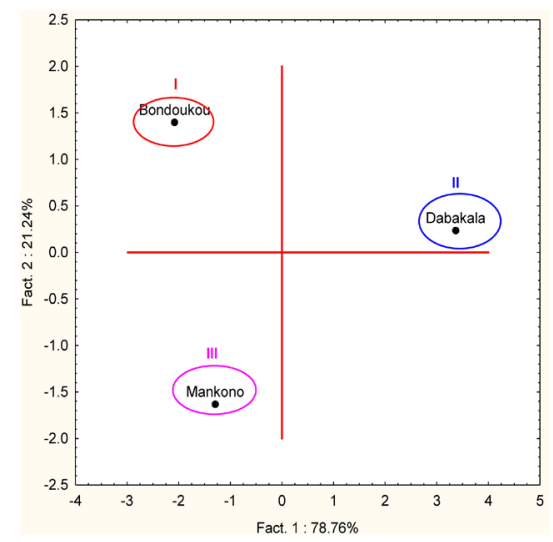

(b)

Figure 3. Projection of physical parameters (a) and representation of cashew nut production areas (b).

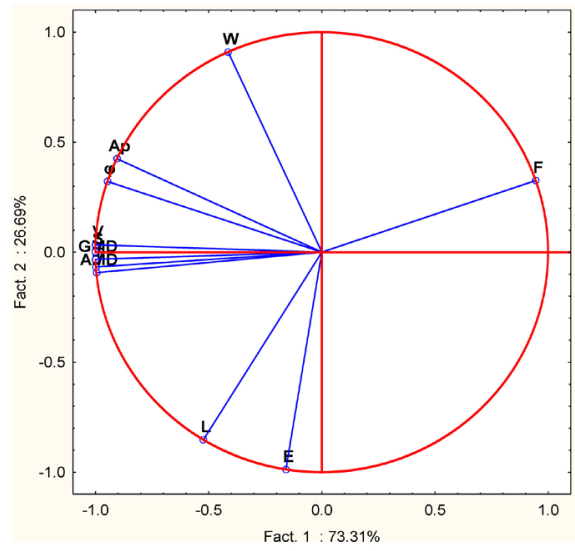

(a)

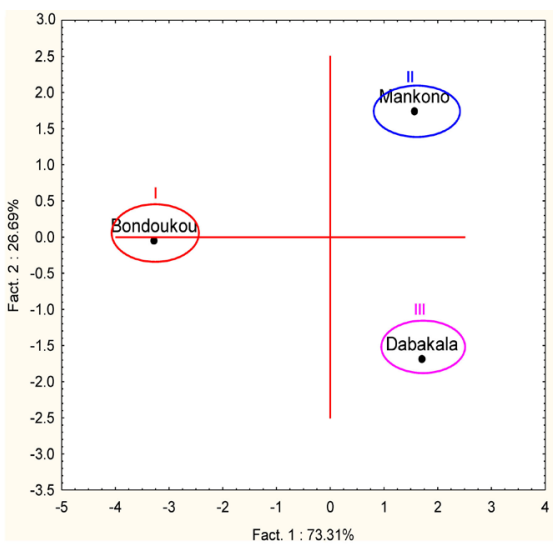

(b)

Figure 4. Projection of physical parameters (a) and representation of production areas (b) of cashew kernel.

\subsection{Quality of Cashew Nuts}

Values of graining, defect rate and outturn of cashew nuts were summarized in Table 4 and Figure 5. The graining of cashew nuts (in mean $160.67 \pm 6.14$ nuts/kg of sample) seemed similar independently to the region. Surprisingly, the weight of health kernels or $100 \%$ accepted was lower at Dabakala (250.23 \pm 3.88 g) as compared to those from Mankono and Bondoukou which were $264.38 \pm$ $0.78 \mathrm{~g}$ and $264.97 \pm 6.14 \mathrm{~g}$ respectively. Indeed, the rate of defects kernels taken together were $11.38 \%$ at Bondoukou, $13.8 \%$ at Mankono and $18.11 \%$ at Dabakala respectively. The diverse causes of Kernels defects observed had been presented in Figure 5. The rate of nuts defect from Mankono was due to immature kernels (52\%) while those of nuts from Bondoukou and Dabakala were due to moulding such as $30 \%$ and $33 \%$ respectively. Thus, the calculation of outturn (KOR) revealed that 46.69 Lbs quality at Bondoukou, 44.09 Lbs quality at Dabakala and 46.59 Lbs quality at Mankono respectively. 


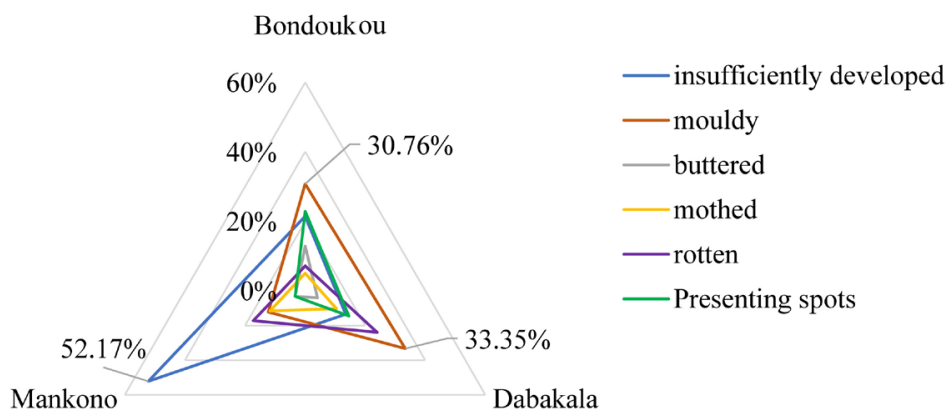

Figure 5. Proportion of characteristic defects of cashew nuts in the different production areas.

\section{Discussion}

Our study was a photography study focused on cashew nuts physical properties from different regions of production in Côte d'Ivoire stored during 6 months. The goal was to evaluate the probable disparities in physical and technological quality of nuts which could be impacted by agricultural practices and local environment. Cashew nuts are today a speculation abundantly produced and Côte d'Ivoire is the first producer and exporter in the world [30]. But, their quality remains moderately acceptable [7] [14] and may be improved. The three main areas of cashew nuts plantations in Côte d'Ivoire are Bondoukou, Dabakala and Mankono which present ecological factors and a diversity of agricultural practices that may impact on the physical and health properties of cashew nuts [3] [19] [20]. The endpoints studied in our study were physical aspects and technological quality of raw cashew nuts after 6 months of storage.

For the physical aspects, the variables followed were moisture content, mass and dimensional of nuts and its parts. In the study, cashew nuts from all three regions have been stored during 6 months under identical conditions namely ambient relative humidity at $77 \%$ and $27^{\circ} \mathrm{C}-28^{\circ} \mathrm{C}$. But, our results reported a disparity in the water content of raw cashew nuts according to the area production after of 6 month of storage. Despite the similar water content before storing, cashew nuts from Mankono showed a rapid water loss as compared to those from Dabakala and Bondoukou probably due to the size or texture of kernels [31]. But, the main factors having impact on the water content in dried raw cashew nuts were namely harvest practice, process and duration of drying, climatic conditions [3] [19] [20] but also the differences in the kernel/shell weight ratio [31]. Indeed, it had been reported that the kernel/shell weight ratio is probably higher in small than in larger nuts and this might explain the slight tendency for the moisture content of heavy nuts to be greater than that of lighter nuts [31]. In contrast, our findings seemed inversely proportional to the moisture content decreasing. Despite the kernel/shell weight ratio higher at Bondoukou, the moisture content diminished very slowly as compared to those of nuts from Dabakala and Mankono. Thus, kernels of nuts from Bondoukou weighted higher than those from Mankono and Dabakala but, surprisingly that not influence the 
weight of whole nut which was similar undependably to the production area. Such particular findings revealed that cashew nuts from Bondoukou in terms of kernel yield presented an advantage which could be promoted in other regions of Côte d'Ivoire since nut weight has been found most stable across environments in cashew [18]. In fact, the kernel yield of cashew nuts produced in Côte d'Ivoire might be improved because of previous studies had reported that at $8 \%$ of water content, kernels weights of cashew nuts Jumbo variety could reach 3.98 $\mathrm{g}$ [18]. For the raw nuts, their weights reported in our study (in mean $6.23 \mathrm{~g}$ ) were higher than those previously reported such as $5.56 \mathrm{~g}$ for Henry and James variety [17], $4.01 \mathrm{~g}$ and $4.14 \mathrm{~g}$ in Senegal but lower as compared to those from Costa Rica (9.75 g) and Nigeria (17.86 $\pm 0.22 \mathrm{~g})$ [17] [18]. Thus, in order to improve the yield of kernels and nuts weights, a recent study has been carried out in Côte d'Ivoire by genotypes selecting [14]. But, the mass of cashew nuts reported in this study $(6.87 \mathrm{~g})$ remained low in comparison to those from Costa Rica and Nigeria [17] [18].

Considering the dimensional aspects of cashew nuts, our results revealed, in large part, similar values. But some particular characteristics have been identified with nuts from Bondoukou which were shorter and their arithmetic mean diameters and sphericity were significantly lower. These particular characteristics were clearer when considered the kernels dimensions properties. Indeed, they were not only thicker but also the values of elongation, fattening, arithmetic and geometric mean diameters, spehricity of kernels from Bondoukou were significantly different to those from Mankono and Dabakala. These different dimensional properties of cashew nuts from diverse origins could be explained by the variety of cashew nuts combined to agro-climatic production conditions [17] [18] [32] [33]. Thus, the nuts in our study were longer $(2.85$ to $2.97 \mathrm{~cm})$ in comparison to those reported from India $(2.5 \mathrm{~cm})$ and varieties of Benin $(2.8 \mathrm{~cm})$, James $(2.64 \mathrm{~cm})$ and Henry $(2.71 \mathrm{~cm})$ respectively [17] [21] but shorter as compared to those $(2.5$ to $3.27 \mathrm{~cm})$ reported by [34]. For the width of nuts, our results $(2.28$ to $2.36 \mathrm{~cm})$ seemed similar to those of nuts from Nigeria (2.04 to 2.49 $\mathrm{cm})$ but lower than Jumbo variety $(3.36 \mathrm{~cm})$ as previously reported [18] [34]. In addition, the thickness (1.64 to $1.67 \mathrm{~cm}$ ) and the sphericity (75\%) of nuts from Côte d'Ivoire were similar in comparison to those reported from Nigeria (1.45 to $1.71 \mathrm{~cm})$ and $(73.71 \%)$ by [34] respectively. Our results have carried out several correlations between physical parameters of nuts or kernels. But, the strongly correlation has been observed with the arithmetic diameter cashew nuts or kernels and their sphericity $(r=0.99)$ respective. Such correlation had been previously reported between mango mass, skin mass, width and thickness $(r=0.9)$ by [27] and between fruit weight and width $(r=0.83)$ by [31] [35].

Despite the differences concerning dimensional aspects of nuts from Côte d'Ivoire, our study revealed that the cashew nuts produced in the three regions were big cashew nuts with graining ranged from 160 to 162 nuts $/ \mathrm{kg}$. The graining of cashew nuts independently of area production was classified excellent 
quality according to the standard size classification of cashew nuts. But, the rate of defects should be posing some concerns. Indeed, after only 6 months of storage, the defective was significant up to about $18 \%$ of total production at Dabakala. Thus, according to rate of defect, with quantity of cashew nuts produced estimated about 30,000 tons, the loss predictable could be 5400 tons at Dabakala. Similarly, the quantities of cashew nuts rejected after 6 months of storage, were 9522 tons and 6515 tons at Mankono and Bondoukou respectively. Thus, taken together the global quantity of cashew nuts rejected after 6 months of storage could be estimated at 21,437 tons on 155,248 tons produced in the three regions. On other hand, the market value of nuts diminished after 6 months of storage more pronounced at Dabakala revealing the need to improve the agricultural practices by farmers in Côte d'Ivoire. Since, the outturn of cashew nuts from Côte d'Ivoire was usually ranged from 46 to $48 \mathrm{lbs}$, only cashew nuts from Bondoukou (46.69 lbs) and Mankono (46.59 lbs) were conformed after 6 months of storage in contrast to those from Dabakala (44.09 lbs). But, according to the Quality standards for raw whole cashew nuts, a good outturn is from 43 to $48 \mathrm{lbs}$ and an excellent out turn from 48 to 55 lbs with the defective lower than 10\%. Thus, the out turn of cashew nuts from the three regions of Côte d'Ivoire remained good after 6 months of storage but the defective exceeding $11 \%$ should be a major concern for the farmers. The causes of cashew nuts defects might be due to agricultural practices namely absence of nuts sorting and insufficient drying which could conduce to fungal contamination and mycotoxins secretion [31] [36]. The significant level of mouldy nuts at Dabakala may also be related to synergistic action due to heavy use of herbicides during nut production [37]. In fact, pesticides use is increasingly recurrent in the maintenance of cashew orchards in this area [30]. Moreover, the high rate of immature nuts in Mankono (7.20\%) showed that producers in this area would not sort their product enough before they were marketed. Sorting would be a production loss for them. Indeed, it had been reported that a loss of $5 \%-15 \%$ of crops such as peanut could be observed during sorting [38].

\section{Conclusion}

In conclusion, cashew nuts produced from Côte d'Ivoire presented some different physical properties namely moisture content lost, width, thickness, length, sphericity and arithmetic mean diameter according to the production area. In terms of kernels yield, nuts from Bondoukou were better and resisted to water lost during the storage as compared to those from Mankono. On the other hand, the defective nuts and values of Outturn found, revealed that farmers from all three regions may improve their agricultural practices.

\section{Acknowledgements}

We are really grateful to ANADER (“Agence National d'Appui au Développement Rural") and COPABO ("Société Coopérative des Producteurs Agricoles de 
Bondoukou") for its help in rural area.

\section{Statement of Credit Author's Contribution}

Yao Stéphane KOFFI: Methodology, Supervision, Software, Formal Analysis, Resources, Data Retention, Research and acquisition of funding. James Halbin KOUADIO: Project Administration, Conceptualization, Methodology, Resources, Data Retention, Supervision, Writing original project, Research and acquisition of funding. Charlemagne NINDJIN: Methodology, Resources.

\section{Conflicts of Interest}

The authors declare no conflicts of interest regarding the publication of this paper.

\section{References}

[1] Sivagurunathan, P., Sivasankari, S. and Muthukkaruppan, S.M. (2010) Characterisation of Cashew Apple (Anacardium occidentale L.) Fruits Collected from Ariyalur District. Journal of Bioscience Research, 1, 101-107.

[2] Dedehou, E., Dossou, J. and Soumanou, M.M. (2015) Etude Diagnostique des Technologies de Transformation de la Pomme de cajou en jus au Bénin. International Journal Biological and Chemical Sciences, 9, 371-387. https://doi.org/10.4314/ijbcs.v9i1.32

[3] Issaka, D.K. (2019) Production de noix de cajou au bénin: État des Lieux et Perspectives Pour 2019. 22 p.

http://www.cashewconvention.com/wcc2019/presentation/Production_de_noix_de _cajou_au_benin_Kassimou_ISSAKA.pdf

[4] Ducroquet, H., Tillie, P., Elouhichi, K. and Gomez, Y.P.S. (2017) L'Agriculture de la Côte d'Ivoire à la Loupe: Etat des Lieux des Filières de Production Végétales et Animales et Revue des Politiques Agricoles (EUR-Scientific and Technical Research Reports). Publications Office of the European Union, Luxembourg, $244 \mathrm{p}$. https://core.ac.uk/download/pdf/154760403.pdf

[5] Gouma, M. (2003) Analyse des Négociations de l'OMC sur l'Agriculture Pour la Formation d'une Politique Appropriée au Développement de la Filière Anacarde en Côte d'Ivoire. Mémoire Professionnel, Université de Cocody, Abidjan, 46 p.

[6] Sinan, A. and Zoumana, C. (2017) Diagnostic Study of Obstacles Related to the Production of Cashew Nuts in the Odienne Region in the North of the Cote d'Ivoire. International Journal of Agricultural Policy and Research, 5, 129-137. https://doi.org/10.15739/IJAPR.17.015

[7] World Bank (2017) Projet d'appui au Secteur Agricole en Côte d'Ivoire (PSAC). http://documents1.worldbank.org/curated/en/310671493977849623/pdf/SFG3314-E A-FRENCH-P155081-Box402905B-PUBLIC-Disclosed-5-3-2017.pdf

[8] Lath, E. (2018) Côte d'Ivoire/Production Agricole: La Filière Anacarde en Crise. http://www.linfodrome.com/economie/43635-cote-d-ivoire-production-agricole-lafiliere-anacarde-en-crise

[9] Ogunwolu, S.O., Yahaya, L.E., Mokwunye, F.C., Ogunjobi, M.A.K. and Olalekan-Adeniran, M.A. (2016) Evaluation of Quality of Raw Cashew (Anacardium occidentale, L) Nut from Major Cashew Producing Areas of Nigeria. American Jour- 
nal of Food Science and Technology, 4, 178-181.

[10] RONGEAD (2010) L'out-Turn ou Comment Mesurer la Qualité de l'Anacarde? 48 p. https://www.nitidae.org/files/9e886694/outurn.pdf

[11] RONGEAD (2008) Apprécier la Qualité des noix de Cajoubrutes. 25 p. https://docplayer.fr/12963603-Apprecier-la-qualite-des-noix-de-cajou-brutes.html

[12] Maia, F., Ribeiro, F., Rangel, H., Lomonaco, D., Luna, F., Lima-Neto, P., Correia, A. and Mazzetto, S. (2015) Evaluation of Antioxidant Action by Electrochemical and Accelerated Oxidation Experiments of Phenolic Compounds Derived from Cashew Nut Shell Liquid. Industrial Crops and Product, 67, 281-286. https://doi.org/10.1016/j.indcrop.2015.01.034

[13] Vicente, A.R., Martínez, G.A., Chaves, A.R. and Civello, P.M. (2006) Effect of Heat Treatment on Strawberry Fruit Damage and Oxidative Metabolism during Storage. Postharvest Biology and Technologie, 40, 116-122. https://doi.org/10.1016/j.postharvbio.2005.12.012

[14] Kouakou, C.K., Adopo, A.A.N., Djaha, A.J.-B., Minhibo, M.Y. and Djidji, A.H. (2017) Sélection de Clones d'Anacardier (Anacardium occidentale L.) de Côte d'Ivoire Pour la Qualité de la noix. Actes du Colloque International d'Échanges Scientifiques sur l'Anacarde, 26-28 October 2017, Grand-Bassam, 13 p.

[15] Mieu, B. (2018) Noix de Cajou: La Côte d'Ivoire Peine à Vendre sa Production. https://www.jeuneafrique.com/562012/economie/noix-de-cajou-la-cote-divoire-pei ne-a-vendre-sa-production/

[16] Narayanan, A. (2016) Vietnam and Cambodia Combined RCN Crop Could Be 500,000-525,000 Tonnes in 2016. Cashew Week, 17, 45-47.

[17] Touré, M., Faye, E., Malou, G., Diatta, M., Arona, S., Samba, N. and Gassama, Y. (2018) Traits Morphométriques et Germination des noix de Anacarde occidentale L. au Sénégal. Afrique Science, 14, 215-226.

https://www.researchgate.net/publication/325615941_Traits_morphometriques_et_ germination_des_noix_de_Anacarde_occidentale_L_au_Senegal.

[18] Adeigbe, O., Adewale, D., Abimbola, M., Olasupo, F., Olaniyi, O., Adenuga, O.A.W. and Aliyu, O. (2016) Quantitative Descriptors of Cashew Nut Categories in Nigeria: Providing Indices for Superior Nut Selection. Journal of Agricultural and Biological Science, 11, 142-148.

[19] Kyriacou, M.C., Leskovar, D.I., Colla, G. and Rouphael, Y. (2018) Watermelon and Melon Fruit Quality: The Genotypic and Agro-Environmental Factors Implicated. Scientia Horticulturae, 234, 393-408. https://doi.org/10.1016/j.scienta.2018.01.032

[20] Bagal, M. and Vittori, M. (2010) Les Indications Géographiques en Côte d'Ivoire, Produits Potentiels et Cadre Juridique Pertinent. ACP Regional Workshops on Geographical Indications, Manuscrit, $43 \mathrm{p}$. https://www.origin-gi.com/images/stories/PDFs/English/OriGIn_in_Action/oif/pap ier\%20pays_cte\%20divoire_origin1.pdf

[21] Balasubramanian, D. (2001) PH-Postharvest Technology: Physical Properties of Raw Cashew Nut. Journal of Agricultural Engineering Research, 78, 291-297. https://doi.org/10.1006/jaer.2000.0603

[22] Ogunsina, B.S. and Bamgboye, A.I. (2012) Effect of Moisture Content, Nut Size and Hot-Oil Roasting Time on the Whole Kernel "Out-Turn" of Cashew Nuts (Anacardium occidentale) during Shelling. Nigerian Food Journal, 30, 57-65. https://doi.org/10.1016/S0189-7241(15)30036-9

[23] N'depo, O.R., Cherif, M., Johnson, F., Kassi, K.F.J.-M., N’Guessan, A.C., Silue, N., 
Akesse, E.N., Kone, D. and N'Goran, O.M. (2017) Inventaire des Insectes Ravageurs du Verger Anacardier dans les Régions de Bounkani, Gontougo et Indénie-Djablun au Nord-Est en Côte d'Ivoire. Afrique Science, 13, 333-343.

https://www.researchgate.net/publication/328412919_Inventaire_des_insectes_rava geurs_du_verger_anacardier_dans_les_regions_de_Bounkani_Gontougo_et_Indeni e-Djablun_au_Nord-Est_en_Cote_d\%27Ivoire

[24] Aboudou, K., Aissi, M.V., Tchobo, F.P., Adankpo, M., Medenouvo, M. and Soumanou, M.M. (2017) Propriétés Physiques et Mécaniques des Fruits Séchés et Amandes de deux Morphotypes de Terminalia catappa Provenant de Trois Types de sols. Afrique Science, 13, 289-303.

[25] Ricau, P. (2013) Connaître et Comprendre le Marché International de l'Anacarde. $49 \mathrm{p}$.

http://www.inter-reseaux.org/IMG/pdf/Guide_RONGEAD__Le_Marche_Internati onal_de_l_Anacarde_v-light.pdf

[26] Association of Official Analytical Chemists (1990) Official Methods of Analysis. 15th Edition, Association of Official Analytical Chemists, Washington DC, 774 p.

[27] Passannet, A.S., Aghofack-Nguemezi, J. and Gatsing, D. (2018) Variabilité des Caractéristiques Physiques des Mangues Cultivées au Tchad: Caractérisation de la Diversité Fonctionnelle. Journal of Applied Biosciences, 128, 12932-12942. https://doi.org/10.4314/jab.v128i1.6

[28] Danebe, K.A., Djeumako, B., Beda, T. and Samon, J.B. (2019) Propriétés Physiques et Mécaniques des Graines et Amandes de Jatropha curcas L. European Scientific Journal, 15, 81-105. https://doi.org/10.19044/esj.2019.v15n36p81

[29] Mirzabe, A.H., Khazaei, J., Chegini, G.R. and Nejad, M.H.A.P.R. (2013) Determination of Some Physical Properties of Virgin Olive Fruits. Agricultural Engineering International, 15, 201-210.

[30] Yao, S.K., James, H.K., Yeboué-Kouamé, B.Y., Joseph, S. and Assanvo, J.E. (2020) Study of Pesticides Use Conditions in Cashew Production in Côte d'Ivoire. Journal of Toxicology and Environmental Health Sciences, 12, 1-9.

[31] Okwelogu, T.N. and Mackay, P.J. (1969) Cashewnut Moisture Relations. Journal of the Science of Food and Agriculture, 20, 697-702. https://doi.org/10.1002/jsfa.2740201201

[32] Ahouansou, R.H., Sanya, E.A., Bagan, G.C. and Foudjet, A.E. (2008) Etude de quelques caractéristiques physiques des noix et amandes de karité produites au Bénin.

https://bec.uac.bj/uploads/publication/28f01f3636f06801971b5a124a9bd54c.pdf

[33] Kelly, B.A. (2005) Impact des Pratiques Humaines sur la Dynamique des Populations et sur la Diversité Génétique de Vitellaria paradoxa (Karité) dans les Systèmes Agro Forestiers au sud Mali. Thèse de Doctorat. Institut Sup. De Formation et Recherche Appliquée, Univ. du Mali, Mali, 243 p.

[34] Kilanko, O. (2018) Design and Performance Evaluation of Centrifugal Cashew Nut Sheller for Improving the Whole Kernel Recovery. Agricultural Engineering International, 20, 162-170.

[35] Combrink, N.K., Labuschagne, M.T. and Bijzet, Z (2013) Variation of Fruit Size and Shape in Kiyomi Tangor Families. Scientia Horticulturae, 162, 357-364. https://doi.org/10.1016/j.scienta.2013.08.010

[36] Manizan, A.L., Akaki, D., Piro-Metayer, I., Montet, D., Brabet, C. and Koffi-Nevry, R. (2018) Évaluation des Pratiques Post Récolte Favorables à la Contamination de 
l'Arachide par les Mycotoxines dans trois Régions de Côte d'Ivoire. Journal of Applied Biosciences, 124, 12446-12454. https://doi.org/10.4314/jab.v124i1.6

[37] Naili, F. (2014) Evaluation de la Rémanence de l'Herbicide Glyphosate dans les Cultures Maraîchères de La Wilaya de Jijel. Université Constantine 1, Algérie, 96 p.

[38] Awuah, R.T., Fialor, S.C., Binns, A.D., Kagochi, J. and Jolly, C.M. (2009) Factors Influencing Market Participants Decision to Sort Groundnuts along the Marketing Chain in Ghana. Peanut Science, 36, 68-76. https://doi.org/10.3146/PS06-36.1 